Shlyahova, S. S., \& Vershinina, M. G. (2016). Fonosemanticheskaya zvukovaya kartina mira [Phonosemantic sound picture of the world]. Perm: Perm National Research Polytechnic University.

Spence, C. (2011). Crossmodal correspondences: A tutorial review. Attention, Perception, \& Psychophysics, 73, 971-995.

Voronin, S. V. (2006) Osnovy fonosemantiki [Basics of phonosemantics]. Moscow: Lenand.

Appleyard, D. (2020). Guide to Phonesthemic Initial Sounds. Retrieved from: https://davidappleyard.com (Accessed 3.02.2021)

Cambridge Dictionary. (2021). Retrieved from: https://dictionary.cambridge.org (Accessed 3.02.2021)

УДК 811.111

https://doi.org/10.25076/vpl.41.02

С.В. Савельев, Н.С Киселева, Ж.В. Стребкова

ГОУ ВО МО «Государственный социально-гуманитарный университет»

\title{
МЕТАФОРИЧЕСКАЯ НОМИНАЦИЯ В \\ ТЕРМИНОСИСТЕМЕ АТОМНОЙ ЭНЕРГЕТИКИ \\ (НА МАТЕРИАЛЕ АНГЛИЙСКОГО ЯЗЫКА): ОПЫТ КОРПУСНОГО И КОГНИТИВНОГО ОПИСАНИЯ
}

В настоящей статье делается попытка рассмотрения проблемы номинации в терминосистеме атомной энергетики и потенциал метафоры как средства номинации. Путем анализа конкретных терминов делается попытка реконструкции когнитивных механизмов номинации $u$ предлагаются продуктивные когнитивные модели номинации в данной терминосистеме.

Верификация результатов обеспечивается за счет применения корпусных методов исследования. Материал исследования позволяет утверждать, что метафора является продуктивным средством номинации объектов и явлений. Более того, такой механизм номинации образует устойчивые и в значительной степени упорядоченные метафорические комплексы.

Наличие таких комплексов позволяет утверждать, что лежащие в основе данных номинаџий модели имеют 
универсальные когнитивные основания, что существенно упрощуает работу по разработке специиальной терминологии, а также экспериментально подтверждает теоретические постулаты терминоведения. Основная масса номинаций основана на переосмыслении терминов родства, биологических прочессов, названия частей тела, оппозиции «верх-низ» и иных сфер человеческой деятельности. Масштабность задачи в значительной степени определило методологическую базу исследования, которое было выполнено как корпуснообусловленное.

Таким образом, анализу были подвергнуты именно статистически репрезентативные явления. Основным инструментом исследования послужсил собранный $и$ автоматически размеченный средствами специализированного программного обеспечения моноязычный корпус объемом 1,1 млн. токенов. Использование данных специилизированного корпуса позволило также проанализировать характер бытования метафор в популярном и профессиональном дискурсе атомной энергетики. Материалом исследования послужили публикации на тему атомной энергетики в популярных электронных средствах массовой информаџии, а так же в специчализированных профессиональных изданиях.

Ключевые слова: терминология, атомная энергетика, метафора, номиначия, дискурс, корпусная лингвистика, лингвокультурология

UDC 811.111

https://doi.org/10.25076/vpl.41.02

S.V. Saveliev, N.S. Kiseleva, Zh.V. Strebkova State University of Humanities and Social Studies

\section{A COGNITIVE AND CORPUS PERSPECTIVE OF METAPHORICAL NOMINATION IN ENGLISH NUCLEAR TERMINOLOGY}

This article attempts to address the problem of nomination in the terminology system of nuclear power and the potential of the metaphor as a means of nomination. By analyzing specific terms of nuclear 
industry, the authors attempt to reconstruct the cognitive mechanisms of nomination and productive cognitive models of the nomination that are used in the terminology of nuclear industry.

The findings are verified using corpus-based methods. The data set used in this study allows to argue that metaphor is a productive means of nomination for the phenomena of nuclear industry. Moreover, such mechanism of nomination allows language users to create stable and consistent clusters terms which sometimes rely upon a single cognitive metaphor.

Arguably, the existence of such clusters means that the models underlying these nominations have universal cognitive foundations, which significantly simplifies the development of special terminologies and confirms a range of theoretical assumptions about the birth of new terms. Nominations in nuclear industry rely on the metaphorical potential of the terms of kinship, biological processes, names of body parts, 'up-down' opposition and other spheres of human activity.

Having compiled a custom corpus of nuclear English, we are able to analyze how these metaphorical nominations work in popular and professional nuclear discourse. The data for the corpus was retrieved from popular and specialized publications, as well as mainstream media.

Keywords: terminology, nuclear power, metaphor, nomination, discourse, corpus linguistics, language and culture studies

\section{Introduction}

It would be safe to say that metaphorical nomination in any language is a culture-dependent phenomenon, as not only does it reflect the way our mind structures the world around us, but also it shows how our culture affects the way we perceive the word. The seminal work of George Lakoff and Mark Johnson provided conclusive evidence for the assumption that mechanisms behind the naming of objects and phenomena in a natural language rely heavily on metaphor, namely cognitive metaphor (Lakoff \& Johnson, 2003). Having gone beyond what is arguably the 'classical' vision of metaphor as a stylistic device, they have looked at it as a method for conceptualizing the world. Thus, we think in metaphors, that is, we notice things around us, notice similarities between them and use these similarities to name new objects. 
The concept of cognitive metaphor becomes particularly important for nominations in specialized subject areas. Any activity in virtually any field of human activity results in the formation of new objects, concepts or phenomena that did not exist before. To name such objects or phenomena the human brain cannot but rely on the proven mechanisms of nomination, i.e. - through cognitive metaphor. Moreover, relying on the images that already exist in our mind, we tend to use the ones that we conspire most fitting the purpose.

Recent studies of scientific discourse and language for professional communication tend to focus on the use and role of metaphor in scientific discourse (see Semino, 2021, Taylor et al. 2018, Leontyeva, 2016, Finatto, 2010, Livnat, 2010) and terminology (Cui, 2021, Bylina et al. 2020, Bucher, 2017, Drouin et al. 2017, Cabre, 1997). At the same time, there is an apparent lack of studies on terminology formation from cognitive perspective. Thus, the role of conceptual metaphor as a mechanism for term creation is often reduced to mere confirmation of its existence. Indeed, it is crucial that the terms, regardless of the subject field are formed consistently and rules behind term formation are observed. Here, as all terminologists know, we witness a constant struggle between terminological neology and linguistic stability. Every change in the system of knowledge requires a parallel change in the system of designation. As these, however, also have to serve the social function of facilitating multilevel communication, they cannot evolve with the same speed. Besides, every theory which needs its own conceptualisation should ideally also have a different terminology for each system of knowledge, even when the objects of knowledge are the same (McCarthy, 2017). This is the typical situation in philosophy and the human sciences, including linguistics and even terminology itself.

In short, scientific terminologies are always inadequate and too stable for reflecting the changing diversity of systems of knowledge. Besides, they are not neatly delimited, with the result that polysemy (one sign for several meanings; one term for several concepts) and synonymy (several terms for one and the same concept), which as a matter of principle should not exist in terminology, are, in fact, very common.

The problem is quite different for nomenclatures, especially in the natural sciences, where the conceptualisation is different in nature. 
In technology the processes of knowledge are vitiated by their social application, their commercialisation, the types of discourse involved, especially that of publicity. Still, the connection between the processes of knowledge acquisition and designation remains primordial. But these processes are quite different. Inasmuch as it is the science of applications, technology is concerned with functional objects, that is to say concepts are not directed towards discovery but towards practical and theoretical usefulness. The special link between terminology and technology resides in the utilitarian relation between invention or technical progress and the systems of designations, all of which are equally - for better or worse - subordinate to this utilitarian purpose. This also applies to abstract techniques like statistics or applied linguistics, despite their close relationship to theoretical knowledge.

Thus, it becomes evident that there is a need to look at terminology creation and as a process of conceptualizing the world through metaphor. Arguably, terms created through the process of metaphorical nomination may have the inherent fallacy of being inconsistent with other terms in the system, yet they allow us to some extent reconstruct the cognitive mechanisms behind the process of nomination. This becomes possible, as term creation is for the most part a deliberate process and, what is important, a creative process. Indeed, looking at the problem from the perspective of linguistics and philosophy (Benz, 2011, Harris, 1988, Stenhouse, 1985) as well as from the perspective of cognitive neuroscience (Becker et al. 2020, Gero et al. 2020, Goel, 2014) we can argue that the process of creating names for new objects and phenomena, i.e. term creation is largely based on the metaphorical rethinking of existing terms or the worlds from everyday language. It is also worth noting that the words used as the sources of metaphor do not have to be explicitly linked to the subject filed. Rather, they may invoke the cultural experiences, which the creator of the term deems fitting.

At this point, it can be assumed that our culture in a very broad sense affects not only the way we describe the world using ordinary language, but also shapes our line of thinking when we use the language in specific, what might be called 'controlled' circumstances. Indeed, following K. Kageura (2002) we see that terms, as compared to the lexis of ordinary language, have more sharply delineated meanings identified as necessary within a particular domain by the complexity 
and number of concepts that have to be clearly distinguished. From the angle of specialised discourse, we can state that some meanings of lexical units are consolidated by clarification and narrower determination in order to satisfy the degree of specification required by the domain in which they are used. However, our natural instinct to play with language and our 'metaphorical' brain often result in violation of this principle.

Thus, in the process of term creation, i.e. nomination of entities in a specific field we see the first basic constraint - the language means at our disposal. A notable example of this are color terms, which tend to vary significantly for the same color across languages (Roberson et al., 2006). Yet, the lack of a term does not mean the lack of concept. In this case metaphor becomes a viable solution, eg. blue vs navy blue. Another constraint is the culture. The sets of cultural phenomena that are essential for a given culture may predefine the image behind nomination. The fact that Greek and Roman mythology are deeply rooted in the culture of the English-speaking world can to an extent explain the naming conventions in the US space program: Atlas and Saturn as names for rockets, Apollo, Gemini, Mercury and Artemis as names for space missions. The choice of names can be explained by the reliance on the imagery and metaphor behind the name of the culturally significant phenomenon. Thus, following Celiešienè (2019) we believe that behind metaphorical nominations are both universal and languagespecific mechanisms. A careful analysis of the existing nominations will allow us to disclose these mechanisms.

\section{Materials and methods}

The collection of the materials for this study presented a significant challenge of both ideological and technical kind. The rationale behind the data set was to create a corpus, which would contain the most common terminology of nuclear industry and at same time would give a consistent picture of the functioning of nuclear terminology in popular and professional discourse. Thus, we decided to rely on corpus linguistics methodology. At this point, we had to solve what may be called a conceptual problem. According to John Sinclair (2004), the 'father' of Corpus Linguistics, 'small is not beautiful; it is simply a limitation' (Sinclair, 2004, p.114). While he concedes that it may be possible, in some cases, to get valid results from a small corpus, he argues that these results will be limited. In a large corpus, on the other 
hand, 'underlying regularities have a better chance of showing through the superficial variations'. To illustrate this, Sinclair looked for the phrase fit into place in a two-million, twenty million and 200-millionword corpus respectively, and did not find any examples until he searched the largest 200-million-word corpus, and even then he only found half a dozen examples. Naturally, this anecdotal example leads to an important conclusion: how will the size of the corpus affect the findings and, more importantly, whether they would contain the examples of metaphorical nominations. Following O'Keeffe \& McCarthy (2012) we argue a small custom corpus fit the purposes of our study as it was intended to be a collection of texts containing specific nuclear terminology, which statistically rare in such corpora of general English as for example Corpus of Contemporary American English (COCA) or British National Corpus (BNC). To create a dedicated corpus of 'nuclear English' we relied on the functionality of SketchEngine corpus manager. Using the white- and blacklist functionality of SketchEngine we, following the procedure described in Kunilovskaya \& Koviazina (2017) compiled a corpus containing at least one of the following lexemes: nuclear, atomic, radioactive, as well as the typical colocations with the lexemes in question, e.g. nuclear energy, atomic energy, nuclear weapons, nuclear waste. The collocations were taken from EnglishWeb corpus 2015 (13 billion words), a General English corpus available in SketchEngine. This allowed us to ensure that the words and collocations that we have found in specialized glossaries, e.g. Hughes (1994) and selected for the whitelist really exist. For our corpus we retrieved the publication from such mainstream British and US media as The Guardian, The Times, The Washington Post, The Economist, The New York Times, as well as specialized media, such as the publications of World Nuclear Association, International Atomic Energy Agency papers and publications of nuclear research facilities in the USA, UK and Canada. Thus, we collected a 1.1 million token corpus, which we deem sufficient for the purposes of our study.

The need to focus on the role of metaphor in term nomination we analyzed the example of nominations using descriptive, contextual, definitional and linguoculturological methods, as well as the method of component analysis. Particular attention was paid to the cognitive analysis, particularly in the case of cognitive metaphor. 
Cultural analysis was employed when culture-bound elements were used for nomination of nuclear industry terms.

\section{Results and discussion}

Analysis of the corpus data showed that metaphorical nomination is indeed used to create the terms of nuclear industry, though such terms are not evenly distributed across the terminological subsets.

The first group of terms that we would like focus on was created using the metaphorical concept of FAMILY RELATIONS. This concept can safely be called one of the key ones, as it reflects the basic relations between people and the also the first formal hierarchy that people experience. It appears that the metaphor of 'family' is most productive for naming the phenomena of the group, which we for the sake of argument called 'Radioactive materials'. Radioactive materials are chemical elements, which exhibit radioactivity that is emitting or relating to the emission of ionizing radiation or particles (IAEA 2007).

Here are the examples of these terms from our corpus:

Mo-99 is the parent isotope of technetium-99m, which ANSTO says is used in about $85 \%$ of all nuclear medicine procedures in Australia.

Featuring a patent-pending neutron capture process, BWXT's technology produces Mo-99, the parent isotope of technetium-99m (Tc$99 \mathrm{~m}$ ), which is used globally in more than 30 million medical procedures each year.

$B W X T^{\prime}$ 's proprietary technology, which was announced in 2018, uses a neutron capture process to produce Mo-99, the parent isotope of Tc$99 \mathrm{~m}$, using natural molybdenum rather than enriched uranium targets

Parent isotopes decay to daughter isotopes at a steady, exponential rate that is constant for each pair.

According to Glossary of nuclear terms and phrases (2017) a parent isotope is the isotope that decays, forming the daughter isotope after releasing a decay particle. Note that the definition itself contains a complementary pair for the metaphorical nomination, i.e. parent daughter. Data from the corpus confirms the existence of such pair:

The isotope technetium-99m (which is the daughter isotope of Mo99) is used in over 40,000 procedures in the USA per day.

Uranium can be separated from its daughter isotope thorium by dissolving a sample in acid and adding sodium iodide, which precipitates thorium(III) iodide.

The decaying isotopes may themselves form stable or unstable 


\section{daughter isotopes .}

Thus, we can assume that the process of naming the process of new isotope creation is metaphorically linked in our brain with the process of giving birth to a child and thus creating descendants. The questions remains though, if we assume that the metaphor behind the nomination is that of giving birth to a child, should not be the pair mother daughter a more likely option, as it better fits the metaphor of parenthood and child birth? Corpus data shows that the option 'mother isotope' does indeed exist and is used in similar contexts, but is less frequent:

The isotope $238 \mathrm{U}$ represents the starting point (mother isotope) of a complex decay chain, finalising in stable $206 \mathrm{~Pb}$.

Molybdenum-99 (Mo-99) is the mother isotope of Technetium-99 (Tc-99).

We, together with IRE, have obviously contributed significantly to the security of supply of medical radio-isotopes ever since, and particularly to the reliable supply by IRE of the $99 \mathrm{Mo}$, the mother isotope of $99 \mathrm{~m} \mathrm{Tc}$, used in some 90000 imaging procedures per day in hospitals all over the word.

Following this line of inquiry, we tested the 'father isotope' and 'son isotope' collocations as potentially fitting into the concept of family relations. These queries did not return any results which, paradoxically confirms the family imagery, as daughter isotopes can later become parents themselves, which could hardly be an option should they have been sons. It seems that the mother (parent) daughter metaphor works for other terminologies, cf: parent company daughter company.

The metaphor of family relations is further developed into what we may call the 'metaphor of reproduction', which is best illustrated with the terms 'breed' / 'breeder' and 'fertile'.

The term 'breeder' refers to a reactor that produces more nuclear fuel than it consumes. This type of reactor is also called fast neutron reactor, which means that the neutrons in it are not 'slowed down' as compared with other reactor types. In the reactor of this type, neutrons hit the nuclei of the atoms thus creating new fuel, hence 'breeding'

The word 'fertile' refers to a material, which is not itself fissile (fissionable by thermal neutrons), that can be converted into a fissile material by irradiation in a reactor. There are two basic fertile 
materials: uranium-238 and thorium-232. When these fertile materials capture neutrons, they are converted into fissile plutonium-239 and uranium-233, respectively. Let us see how these examples of metaphorically nominated terms behave in context:

The uranium is bred into plutonium, which undergoes fission, in a 'wave' that moves through the core at only one centimetre per year, in what has been likened to a 'candle reactor' as the wave 'burns' from one end of the reactor to the other.

Asked about this, Kingham said fusion will initially use tritium and deuterium as fuel, and the tritium will be bred from lithium within the tokamak device.

The core design of the original TWR concept envisages a moving region, or 'wave', in which the uranium is bred progressively into plutonium, which is the actual fuel that undergoes fission.

It also called for fast breeder reactors to be introduced commercially, but not until about 2050.

The reactor could be operated as a breeder or not.

The circulation speed of the fuel loop can be adjusted for various purposes such as maximum burn-up, transuranium element incineration, isotope production, fertile material conversion (aka breeding), specific deactivation of fission products, etc.

During operation the reactor breeds more fissile material from fertile material.

Uranium-238 is not fissile, but is a fertile isotope, because after neutron activation it can produce plutonium-239, another fissile isotope.

This can be conceptualized by considering that one of the neutrons must go on to cause another reaction, while yet another must be used to breed a fertile isotope.

This set of examples provides an interesting insight into how the metaphor of reproduction is employed to create a consistent picture of the process inside a nuclear reactor. Let us start deconstructing the metaphorical nomination from the component 'fertile'. From the definition given earlier we know that a fertile isotope is the isotope which, if hit by a neutron can absorb it and thus become fissile, that is ready to split and release a particle and some energy. Thus we see that this process resembles that of impregnation, of which breeding is an essential stage. The co-existence of two synonymous terms for this 
reactor type, i.e. 'fast neutron reactor' and 'breeder reactor' shows that the choice of metaphor behind the nomination is driven by the aspect of the reactor technology under discussion and functions as a limit, which means that the likelihood of co-occurrence of such term as fertile isotope is higher in the context with breeder reactor than with fast neutron reactor. Thus, we can say that the metaphor of family relations is used consistently for nomination of phenomena in nuclear industry and forms a whole cluster of interrelated terms. However, this consistency is to an extent challenged by the term 'orphan source'. Following the definition from IAEA Safety Glossary, an 'orphan source' is a radioactive source which is not under regulatory control, either because it has never been under regulatory control or because it has been abandoned, lost, misplaced, stolen or otherwise transferred without proper authorization. From the first glance it may appear that this term does not fit into the metaphorical cluster of 'family relations', yet corpus data prove the opposite:

In this regard, NSAP is striving hard to locate, recover and provide "safe home" to such orphan sources.

It is not about leaving radioactive waste stranded at hospitals or the so-called orphan source problem where materials are lost or misplaced.

Orphan sources are defined as "sources not under regulatory control, either because they have never been under regulatory control or because they have been abandoned, lost, misplaced, stolen or transferred without proper authorization."

Even in advanced countries, every year administrative control is lost over many radioactive sources making them orphan sources.

As it can be seen from the examples from the corpus, the term 'orphan source' is often explained though the imagery of a lost child, cf: find a safe home, lost, abandoned, stolen. In this instance of metaphorical nomination we see how the periphery of the concept drives the process of term creation. The lack of control over radioactive material is conceptualized through the lack of what is arguably the most important type of relation for us as species, i.e. the lack of parental relations. The emotional coloring which the metaphor gives the term, provokes not only vivid imagery of a lost child, but also acts as a obfuscated call for action, i.e. to 'recover' the source and 'bring it home' 
As much as the metaphor of family relations, the metaphor of geography appears to be a productive source of terms for nuclear industry. Metaphors of geographical objects tend to be a very productive and commonly used methods of nomination cf: No man is an island entire of itself; // every man is a piece of the continent, a part of the main (Donne, 1988), <..> Or to take arms against the sea of troubles (Shakespeare 2017). Here we cannot but ignore idioms, e.g. as old as the hills, to make a mountain of a molehill, to hit the rocks, the coast is clear etc. (Ayto, 2020).

Corpus data shows that the metaphor of island tends to be one of the most popular in the nuclear industry. The most typical instances of metaphorical nomination being the collocations 'nuclear island':

First concrete was poured for the nuclear island of Fangchenggang unit 3 in December 2015, while that for unit 4 was poured a year later.

Decommissioning of the nuclear island of the Trino Vercellese nuclear power plant in Italy is now under way.

Construction of the 49,000-tonne concrete basemat for the nuclear island of the second unit at Hinkley Point $C$ has been completed.

The RPV was lifted into its permanent location in Vogtle 4's nuclear island on 29 March, Georgia Power has announced.

Cold testing of the nuclear island of the unit was successfully completed in October 2012 and it achieved first criticality on 16 January.

Carried out before the loading of nuclear fuel, such testing simulates the thermal working conditions of the power plant and verifies that nuclear island and conventional equipment and systems meet design requirements.

As well as 'conventional island':

The conventional island suppliers are ZIPP for the civil works; Škoda Power and Modrany Power for the mechanical systems; and $\check{C} K D$, PPA, Energo \& Schneider, Brush SEM and Techimp for the electrical systems and equipment.

Contracts dealing with the engineering, construction and project management of the conventional island were signed with Italy's Enel Ingegneria \& Innovazione

It was established in 2007 to offer comprehensive solutions for the conventional island of VVER plants.

However, site preparations for the units are well advanced with the 
pouring of concrete for the foundations of the first unit's conventional island having now begun.

The term 'nuclear island' refers to that part of a nuclear power plant which incorporates all equipment, systems, installation and control and other relevant hardware installed within the reactor and reactor auxiliary buildings. Thus, 'conventional island' is the part of the nuclear power plant which houses the key component which extracts thermal energy from pressurized steam generated by the nuclear reactor and converts it into electrical energy. The apparent abundance of the term nuclear island as compared to conventional island can be explained by the fact that the equipment located on the nuclear island is foreseeably more often discussed. In the process of nomination, such feature of an island as isolation is emphasized. Indeed, restricted access and physical barriers separating the 'nuclear' and the 'conventional' islands create this impression, and the green lawns, so very typical for nuclear power plants intensify the imagery of the 'sea' around islands.

The metaphor of an island in a sea is arguably best portrayed in the term '(nuclear) island of stability', which is commonly defined in nuclear physics as a predicted set of isotopes of superheavy elements that may have considerably longer half-lives than known isotopes of these elements. It is predicted to appear as an "island" in the chart of nuclides, separated from known stable and long-lived primordial radionuclides (Oganessian, 2015). As compared with what we may call more 'technical' terminology, where terminological rigor is more often observed, the terminology of nuclear science, including scientific publications for the general public tend to show a tendency for consistent use of geographical metaphor:

This interpretation of a new nuclear structure is of great importance, but it has significance far beyond itself because the theoretical method and other novel approaches to calculation of nuclear stability have been used to predict an island of stability beyond the point at which the peninsula in the Figure disappears into the sea of instability.

The researchers say that the discovery bolsters the idea of an' island of stability ' among still heavier elements.

Based on the ideas of the 1960s, we thought when we got to element 114 we would have reached the Island of Stability.

The discovery is a major step toward understanding how to explore 
the long-sought Island of Stability, which is thought to lie in the vicinity of element 114 - and possibly beyond.

Information gained from the new isotopes will contribute to a better understanding of the theory of nuclear shell structure, which underlies predictions of an "Island of Stability, " a group of long-lasting isotopes thought to exist amidst a sea of much shorter-lived, intrinsically unstable isotopes of the superheavy elements.

A beachhead on the island of stability Recent experiments to synthesize the heaviest elements have dramatically expanded the periodic table and the Segrè chart of nuclides

As it can be seen from the examples from the corpus, the term island is used with the modifier (stability) which significantly affects the way metaphorical nomination works. This results of the consistent usage of the pairs of antonyms: island of stability vs sea of instability. The image of the island is further exploited as language users rethink the visual images used for data presentation. Thus, the area on the chart of superheavy isotopes where stable isotopes start to appear is termed 'beachhead' which invokes both geographical and war imagery, cf: 'The battle secured the beachheads of the U.S. Sixth Army on Leyte against attack from the sea, broke the back of Japanese naval power and opened the way for an advance to the Ryukyu Islands in 1945.' This, metaphorical nomination resulted in the emerging of a new conceptual metaphor: 'research is a battle'. Thus, the metaphor used to nominate the search for superheavy elements invokes the imagery of navigating dangerous waters and and setting foot on hostile shores which are to be conquered.

\section{Conclusion}

Results of current research in the philosophy of language, cognitive linguistics and terminology show that metaphor is at the heart of the process of nomination. Indeed, its power to highlight granular aspects of meaning and use them for the purposes of nomination have not only been decisively proven, but also contributed to our understanding of the cognitive mechanisms behind the process of nomination. Data from neuroscience shows that even in very non-creative linguistic environments people tend to utilize the potential of metaphor as method of entity nomination and thus display significant linguistic creativity. These observations seem to contradict the principles that form the theoretical foundations of terminology and terminography, where 
consistency and transparency of meaning are key. Yet, a closer look that the history and current state of terminology show, that metaphor has been part and parcel of term creation early on. Current studies in terminology, though not as numerous as we would expect, show that metaphor is still a power tool of term creation. Yet, most studies of metaphor in technical or scientific communication rarely go beyond mere stating of the fact that metaphor can be used for term creation. Thus, we attempted to show how a whole cluster of terms can spring out of one metaphor.

For our study, we chose the terminology of nuclear energy. The choice, apart from personal likings, was predetermined by the fact that terminology in nuclear industry comes from a very limited amount of sources, which to an extent reduces the factor of regional or 'crosscorporate' variation; overall tendency for consistency (Wells, 2018), driven by the need for unhindered communication within the professional community globally. An apparently small of studies in the terminology of nuclear energy also drew our ambition to chart this terminological space. To achieve consistent and verifiable results we decided to make our study corpus-based and corpus-driven, which meant that we took the examples for analysis from a dedicated corpus. At the same time, at the point of compilation we did not fine tune the data retrieval engine, which meant, that at the moment of making the first search query we did not know, whether the terms created through metaphorical nomination had been added to the corpus of not. The data for the corpus was retrieved from British and US mainstream quality media and publications from specialized professional media, public research institutions and IAEA. Thus, the corpus yielded balanced results.

The results of the study showed that the metaphor of kinship is widely used for the purposes of coining new terms, and is lined to the metaphor of procreation, which we did not initially assume to be popular. Another interesting case was the metaphor of island, which is used consistently across terminological sub-systems and brings about the conceptual metaphor RESEARCH IS A STRUGGLE. It can be assumed that corpus expansion may provide further examples of metaphorical nomination. 


\section{Литература}

1. Ayto J. Oxford dictionary of idioms. New York: Oxford University Press, 2010.

2. Becker M., Kühn S., Sommer T. Verbal insight revisited Dissociable neurocognitive processes underlying solutions accompanied by an AHA! experience with and without prior restructuring. Режим доступа: https://doi.org/10.31234/osf.io/pm95e (дата обращения 21.01.2021)

3. Benz A. Language, games, and evolution: Trends in current research on language and game theory // Texts in logic and games. Vol. 6207. Berlin: Springer, 2011.

4. Bucher A. L. Terminology work in Sweden// Studi@ Naukowe 2017. № 38. Warsaw. Pp. 266-282.

5. Bylina E. E., $\quad$ Sludneva L. V., $\quad$ Skopintseva T. A., Yurkovskaya E. A. Current Trends in the Development of Professional Discourse Terminology of Logistics // In Proceedings of the International Session on Factors of Regional Extensive Development (FRED 2019). Paris, France: Atlantis Press, 2020. Режим доступа: https://doi.org/10.2991/fred-19.2020.26 (дата обращения 21.01.2021)

6. Cabré M. T., Sager J. C. Terminology: Theory, methods, and applications / M. Teresa Cabré; edited by Juan C. Sager; translated by Janet Ann DeCesaris. Terminology and lexicography research and practice, 1388-8455: v.1. Amsterdam: J. Benjamins Pub. Co., 1999.

7. Celiešienè V., Juzelènienè S. Metaphorical Nomination in IT Terminology in Lithuanian and English Languages // Journal of Language and Cultural Education. 2019. №7 (1). Pp. 84-102. Режим доступа: https://doi.org/10.2478/jolace-2019-0006

8. Cui M. Key Concepts and Terminology. In L. Liu \& S. Ramakrishna (Eds.). An Introduction to Circular Economy (pp. 17-34). Singapore: Springer Singapore, 2021. Режим доступа: https://doi.org/10.1007/978-981-15-8510-4_2 (дата обращения 21.01.2021)

9. Donne J., Lush H. No man is an island. London: Souvenir, 1999.

10. Drouin P., Francœur A., Humbley J., Picton A. Multiple Perspectives on Terminological Variation (Vol. 18). Amsterdam: 
John Benjamins Publishing Company, 2017. Режим доступа: https://doi.org/10.1075/tlrp.18 (дата обращения 21.01.2021)

11. Finatto M. J. B. Metaphors in scientific and technical languages: challenges and perspective // DELTA: Documentação De Estudos Em Lingüística Teórica E Aplicada. 2010. Vol.26 (spe). Pp. 645656. Режим доступа: https://doi.org/10.1590/S010244502010000300012 (дата обращения 21.01.2021)

12. Gero J. S., Milovanovic J. (2020). A framework for studying design thinking through measuring designers' minds, bodies and brains // Design Science. 2020. №6. Режим доступа: https://doi.org/10.1017/dsj.2020.15 (дата обращения 21.01.2021)

13. Goel V. Creative brains: Designing in the real world // Frontiers in Human Neuroscience. 2014. №8. Режим доступа: https://doi.org/10.3389/fnhum.2014.00241 (дата обращения 21.01.2021)

14. Harris R. Language, Saussure and Wittgenstein: How to play games with words. Routledge history of linguistic thought series. London: Routledge, 1988.

15. Hughes D. E. E. Glossary of civil nuclear terms: For use by the media in the event of a nuclear emergency, 1994.

16. IAEA safety glossary: Terminology used in nuclear safety and radiation protection. Vienna: IAEA, 2007.

17. Glossary of nuclear terms and phrases: A glossary of commonly used nuclear terms and phrases with a short explanation for each. Stevenage, Herts: The Institution of Engineering and Technology, 2017.

18. Kageura K. The dynamics of terminology: A descriptiove theory of term formation and terminological growth. Terminology and lexicography research and practice, 1388-8455. Vol. 5. Amsterdam: J. Benjamins Pub. Co., 2002.

19. Kunilovskaya M., Koviazina M. Sketch Engine: A Toolbox for Linguistic Discovery // Journal of Linguistics/Jazykovedný Casopis. 2017. Vol. 68(3). Рp. 503-507. Режим доступа: https://doi.org/10.2478/jazcas-2018-0006 (дата обращения 21.01.2021)

20. Lakoff G., Johnson M. Metaphors we live by. Chicago, Ill., London: University of Chicago Press, 2003. 
21. Leontyeva A. V. Metaphor in Scientific Discourse // Voprosy Kognitivnoy Lingvistiki. 2016. №(3). Рp. 128-133. Режим доступа: https://doi.org/10.20916/1812-3228-2016-3-128-133 (дата обращения 21.01.2021)

22. McCarthy M. Usage on the move: Evolution and re-volution. Training, Language and Culture. 2017. №1(2). Pp. 8-21. Doi: 10.29366/2017tlc.1.2.1

23. Oganessian Y. T., Rykaczewski, K. P. 2015. A beachhead on the island of stability // Physics Today. 2015. Vol. 68(8). Pp. 32-38. Режим доступа: https://doi.org/10.1063/PT.3.2880 (дата обращения 21.01.2021)

24. O'Keeffe A., McCarthy M. The Routledge handbook of corpus linguistics. Routledge handbooks. Milton Park, Abingdon, Oxon, New York: Routledge, 2012.

25. Roberson D., Davidoff J., Davies I. R., Shapiro L. R. Colour categories and category acquisition in Himba and English. In N. Pitchford \& C. P. Biggam (Eds.) // Progress in Colour Studies. 2006. Pp. 159-172. Amsterdam: John Benjamins Publishing Company, 2006. Режим доступа: https://doi.org/10.1075/z.pics2.14rob (дата обращения 21.01.2021)

26. Shakespeare W., Icke R. Hamlet. London: Oberon Books, 2017.

27. Semino E. "Not Soldiers but Fire-fighters" - Metaphors and Covid19 // Health Communication. 2021. Vol. 36(1). Pp. 50-58. Режим доступа: https://doi.org/10.1080/10410236.2020.1844989(дата обращения 21.01.2021)

28. Sinclair J., Carter R. Trust the text: Language, corpus and discourse. London: Routledge, 2004.

29. Stenhouse D. Active philosophy in education and science: Paradigms and language games. London: Allen \& Unwin, 1985.

30. Taylor C., Dewsbury B. M. On the Problem and Promise of Metaphor Use in Science and Science Communication // Journal of Microbiology \& Biology Education. 2018. Vol. 19(1). Режим доступа: $\quad$ https://doi.org/10.1128/jmbe.v19i1.1538(дата обращения 21.01.2021)

31. Wells A. Slang, Jargon, and More. In A. Wells (Ed.) // The Tech Professional's Guide to Communicating in a Global Workplace. 
Berkeley, CA: Apress. 2018. Рp. 89-105. Режим доступа: https://doi.org/10.1007/978-1-4842-3471-6_5(дата обращения 21.01.2021)

\section{References}

Ayto, J. (2020). Oxford dictionary of idioms (4th ed.). New York: Oxford University Press.

Becker, M., Kühn, S., \& Sommer, T. (2020). Verbal insight revisited Dissociable neurocognitive processes underlying solutions accompanied by an AHA! experience with and without prior restructuring. https://doi.org/10.31234/osf.io/pm95e

Benz, A. (2011). Language, games, and evolution: Trends in current research on language and game theory. In Anton Benz et al. (Eds.), Texts in logic and games. Vol. 6207. Berlin: Springer.

Bucher, A. L. (2017). Terminology work in Sweden. Studi@ Naukowe 38, 266.

Bylina, E. E., $\quad$ Sludneva, L. V., $\quad$ Skopintseva, T. A., \& Yurkovskaya, E. A. (2020). Current Trends in the Development of Professional Discourse Terminology of Logistics. In Proceedings of the International Session on Factors of Regional Extensive Development (FRED 2019). Paris, France: Atlantis Press. https://doi.org/10.2991/fred-19.2020.26

Cabré, M. T., \& Sager, J. C. (1999). Terminology: Theory, methods, and applications. In Juan C. Sager (Ed.), Terminology and lexicography research and practice, 1388-8455. Vol.1. Amsterdam: J. Benjamins Pub. Co.

Celiešienè, V., \& Juzelènienè, S. (2019). Metaphorical Nomination in IT Terminology in Lithuanian and English Languages. Journal of Language and Cultural Education, 7(1), 84-102. https://doi.org/10.2478/jolace-2019-0006

Cui, M. (2021). Key Concepts and Terminology. In L. Liu \& S. Ramakrishna (Eds.), An Introduction to Circular Economy (pp. 1734). Singapore: Springer Singapore. https://doi.org/10.1007/978981-15-8510-4_2

Donne, J., \& Lush, H. (1988 (1999 [printing])). No man is an island. London: Souvenir.

Drouin, P., Francœur, A., Humbley, J., \& Picton, A. (2017). Multiple Perspectives on Terminological Variation (Vol. 18). Amsterdam: 
John Benjamins Publishing Company. https://doi.org/10.1075/tlrp.18

Finatto, M. J. B. (2010). Metaphors in scientific and technical languages: challenges and perspective. DELTA: Documentação De Estudos Em Lingüistica Teórica E Aplicada, 26(spe), 645-656. https://doi.org/10.1590/S0102-44502010000300012

Gero, J. S., \& Milovanovic, J. (2020). A framework for studying design thinking through measuring designers' minds, bodies and brains. Design Science, 6. https://doi.org/10.1017/dsj.2020.15

Goel, V. (2014). Creative brains: Designing in the real world. Frontiers in Human Neuroscience, 241. https://doi.org/10.3389/fnhum.2014.00241

Harris, R. (1988). Language, Saussure and Wittgenstein: How to play games with words. Routledge history of linguistic thought series. London: Routledge.

Hughes, D. E. E. (1994). Glossary of civil nuclear terms: For use by the media in the event of a nuclear emergency.

IAEA safety glossary: Terminology used in nuclear safety and radiation protection (2007 ed.) (2007). Vienna: IAEA.

Institution of Engineering and Technology, publisher (2017). Glossary of nuclear terms and phrases: A glossary of commonly used nuclear terms and phrases with a short explanation for each. Stevenage, Herts: The Institution of Engineering and Technology.

Kageura, K. (2002). The dynamics of terminology: A descriptiove theory of term formation and terminological growth. Terminology and lexicography research and practice, 1388-8455. Vol. 5. Amsterdam: J. Benjamins Pub. Co.

Kunilovskaya, M., \& Koviazina, M. (2017). Sketch Engine: A Toolbox for Linguistic Discovery. Journal of Linguistics/Jazykovedný Casopis, 68(3), 503-507. https://doi.org/10.2478/jazcas-2018-0006

Lakoff, G., \& Johnson, M. (2003). Metaphors we live by. Chicago, Ill., London: University of Chicago Press.

Leontyeva, A. V. (2016). Metaphor in scientific discourse. Voprosy Kognitivnoy Lingvistiki, 3, 128-133. https://doi.org/10.20916/18123228-2016-3-128-133

McCarthy, M. (2017). Usage on the move: Evolution and re-volution. Training, Language and Culture, 1(2), 8-21. Doi: 10.29366/2017tlc.1.2.1 
Oganessian, Y. T., \& Rykaczewski, K. P. (2015). A beachhead on the island of stability. Physics Today, 68(8), 32-38. https://doi.org/10.1063/PT.3.2880

O'Keeffe, A., \& McCarthy, M. (2012). The Routledge handbook of corpus linguistics. Milton Park, Abingdon, Oxon, New York: Routledge.

Roberson, D., Davidoff, J., Davies, I. R., \& Shapiro, L. R. (2006). Colour categories and category acquisition in Himba and English. In N. Pitchford \& C. P. Biggam (Eds.), Progress in Colour Studies (pp. 159-172). Amsterdam: John Benjamins Publishing Company. https://doi.org/10.1075/z.pics2.14rob

Shakespeare, W., \& Icke, R. (2017). Hamlet. London: Oberon Books.

Semino, E. (2021). "Not Soldiers but Fire-fighters" - Metaphors and Covid-19. Health Communication, 36(1), 50-58. https://doi.org/10.1080/10410236.2020.1844989

Sinclair, J., \& Carter, R. (2004). Trust the text: Language, corpus and discourse / John Sinclair; edited with Ronald Carter. London: Routledge.

Stenhouse, D. (1985). Active philosophy in education and science: Paradigms and language games / David Stenhouse. London: Allen \& Unwin.

Taylor, C., \& Dewsbury, B. M. (2018). On the Problem and Promise of Metaphor Use in Science and Science Communication. Journal of Microbiology \& Biology Education, 19(1). https://doi.org/10.1128/jmbe.v19i1.1538

Wells, A. (2018). Slang, Jargon, and More. In A. Wells (Ed.), The Tech Professional's Guide to Communicating in a Global Workplace (pp. 89-105). Berkeley, CA: Apress. https://doi.org/10.1007/978-14842-3471-6 5 